\title{
Simulations of Ozone Feedback Effects on the Equatorial Quasi-Biennial Oscillation with a Chemistry-Climate Model
}

\author{
Kiyotaka Shibata
}

check for updates

Citation: Shibata, K. Simulations of Ozone Feedback Effects on the Equatorial Quasi-Biennial Oscillation with a Chemistry-Climate Model. Climate 2021, 9, 123. https:// doi.org/10.3390/cli9080123

Academic Editor:

Harry D. Kambezidis

Received: 1 June 2021

Accepted: 23 July 2021

Published: 29 July 2021

Publisher's Note: MDPI stays neutral with regard to jurisdictional claims in published maps and institutional affiliations.

Copyright: (C) 2021 by the author. Licensee MDPI, Basel, Switzerland. This article is an open access article distributed under the terms and conditions of the Creative Commons Attribution (CC BY) license (https:/ / creativecommons.org/licenses/by/ $4.0 /)$.
School of Environmental Science and Engineering, Kochi University of Technology, 185 Miyanokuchi, Tosayamada, Kami 782-8502, Kochi, Japan; shibata.kiyotaka@kochi-tech.ac.jp

\begin{abstract}
Ozone feedback effects on the quasi-biennial oscillation (QBO) were investigated with a chemistry-climate model (CCM) by modifying ozone abundance in the radiative process. Under a standard run for 50 years, the CCM could realistically reproduce the QBO of about a 28-month period for wind and ozone. Five experiment runs were made for 20 years through varying ozone abundance only in the equatorial stratosphere from 100 to $10 \mathrm{hPa}$ by $-40,-20,-10,+10$, and $+20 \%$, respectively, after the chemistry module and transferring the resultant ozone to the radiation calculation. It was found that the modification of ozone abundance in the radiation substantially changed the period of the QBO but slightly influenced the amplitude of the QBO. The $10 \%$ and $20 \%$ increase runs led to longer QBO periods (31 and 34 months) than that of the standard run, i.e., lengthening by 3 and 6 months, while the $10 \%, 20 \%$, and $40 \%$ decrease runs resulted in shorter periods $(24,22$, and 17 months), i.e., shortening by 4,6 , and 11 months. These substantial changes in the QBO period in the experiment runs indicate that the ozone feedback significantly affects the QBO dynamics through the modulation in solar heating.
\end{abstract}

Keywords: quasi-biennial oscillation; stratospheric ozone; chemistry-climate model; ozone feedback effect

\section{Introduction}

Ozone absorbs solar radiation very strongly in ultra-violet wavelengths as well as weakly in visible wavelengths, and in infrared wavelengths ozone strongly absorbs and emits radiation in a $9.6 \mu \mathrm{m}$ band in the middle of the terrestrial radiation of the warm earth's surface. Ozone thereby has crucial effects on the thermal structure in the middle atmosphere through radiation. Since ozone is distributed not uniformly in the atmosphere, being different from other major radiatively active gases such as $\mathrm{CO}_{2}$ and $\mathrm{CH}_{4}$, it is very important to use as accurate as possible data for prescribed ozone in general circulation models (GCMs) for realistic simulations of the current climate (e.g., [1,2]). Also for reliable assessment of ozone and dynamics in the recent past hindcast and future climate projection of the middle atmosphere, it is very preferable or indispensable to interactively incorporate ozone chemistry into numerical models as in chemistry-climate models (CCMs) (e.g., [3,4]).

Over the tropical stratosphere, there dominate internal variabilities of the quasibiennial oscillation (QBO) in zonal wind [5,6], which are much larger than those due to the annual cycle, being different from those over the extratropical stratosphere. Along with the QBO in dynamics, a similar oscillation in ozone was reported $[7,8]$ and is referred to as the ozone QBO. The basic mechanism of the QBO is attributed to the interaction with the mean flow of the waves propagating upward from the tropical troposphere at a broad range of spatiotemporal scales $[9,10]$. Meanwhile, the latitudinal structure of the QBO is mainly attributed to the secondary circulation, i.e., the mean meridional circulation due to the QBO [11], by which long-lived chemical species such as odd oxygen $\left(\mathrm{O}_{3}+\mathrm{O}\right)$ are transported.

This paper will focus on the feedback effects of ozone through radiative (mostly solar) heating on the QBO, which some studies have demonstrated causes crucial modulations 
of the dynamical characteristics of the QBO. The important role of the ozone radiative feedback on the QBO was first pointed out in a two-dimensional (2D) model simulation showing that local anomalous ozone, due to vertical advection, causes a local heating anomaly, affecting the QBO through weakening/intensifying of the residual mean circulation [12]. Also in a mechanistic 1D model with a simple linear damping for ozone chemistry, the ozone solar heating feedback was demonstrated to be key to reproducing the phase relation among ozone, zonal wind, and temperature in the QBO in the lower stratosphere [13]. However, the aspects of where the ozone feedback significantly appears were not necessarily the same, depending on the frameworks of models employed. In 2D model simulations, the ozone radiative feedback made a significant contribution to the temperature amplitude of the QBO $[14,15]$ as well as the zonal wind amplitude of the QBO and the magnitude of the meridional circulation [15]. On the other hand, another 2D model simulation demonstrated that the effect of the QBO in solar heating on the ozone and meridional circulation oscillations was negligible [16]. The ozone radiative feedback was also reported to stabilize the QBO against perturbations by volcanic aerosols in a 1D model simulation [17].

The ozone radiative feedback on the QBO was also investigated with 3D models through the comparison between interactive and non-interactive ozone simulations [18-20], which is virtually equivalent with the comparison between CCM and GCM simulations. In $\mathrm{CCM}$ simulations with prescribed long-lived species such as $\mathrm{NO}_{\mathrm{y}}, \mathrm{Cl}_{\mathrm{y}}$, and $\mathrm{Br}_{\mathrm{y}}$, the ozone radiative feedback led to an increase of 3 months in the QBO period [18]. In CCM simulations with full chemistry and transport, the ozone radiative feedback prolonged the QBO period by 11 or 21 months, depending on the setting in gravity wave parameterization [19], or 4 months [20]. Even replacing a prescribed zonally uniform ozone dataset in a GCM resulted in a 12-month increase in the QBO period [2]. These 3D model simulations clearly demonstrated a close relationship between ozone and dynamics.

This paper is to investigate the ozone radiative feedback on the QBO with a CCM thoroughly holding the interaction between chemistry and dynamics. That is, ozone is always treated interactively throughout the investigation, being in high contrast to the previous studies of the comparison of interactive and non-interactive ozone simulations [18-20]. The ozone abundance calculated in the chemistry module of the CCM was modified (i.e., increased or decreased) in the tropical stratosphere, and then the modified ozone abundance was transferred to the dynamics module, which included radiative calculation. The modification of ozone abundance was not made outside the tropical stratosphere. It was found that the modification of ozone abundance substantially changed the period of the $\mathrm{QBO}$ and influenced, to a lesser extent, the amplitude of the QBO. Compared to the QBO period of 28 months in a standard simulation, ozone $10 \%$ and $20 \%$ increase runs led to longer QBO periods ( $\sim 31$ and 34 months), i.e., lengthening by 3 and 6 months, while ozone $10 \%, 20 \%$, and $40 \%$ decrease runs resulted in shorter periods ( 24,22 , and 17 months), i.e., shortening by 4,6 , and 11 months.

The rest of this paper is organized as follows. Section 2 describes the model and simulation conditions. Section 3 presents the results of the simulated QBO in dynamics and ozone. Section 4 is the discussion, and Section 5 provides conclusions.

\section{Model and Simulations}

The model used in this study is the CCM of the Meteorological Research Institute (MRI) of Japan (MRI-CCM). Specifications of the MRI-CCM are described in another paper [21,22] and references therein, so that only a brief description of its dynamics and chemistry is provided here. The dynamics module of MRI-CCM is an atmospheric spectral global model with triangular truncation, a maximum total wavenumber 42 (T42, about $2.8^{\circ}$ by $2.8^{\circ}$ in longitude and latitude grid space), and 81 layers in the terrain-following eta-coordinate with a lid at $0.01 \mathrm{hPa}$ (about $80 \mathrm{~km}$ ). Non-orographic gravity-wave forcing by Hines [23] is incorporated with an enhanced source strength in the tropics. Biharmonic $\left(\Delta^{2}\right)$ horizontal diffusion is minimized only in the middle atmosphere compared to that in the troposphere 
to spontaneously reproduce the QBO while minimizing the changes in the troposphere [19]. In addition, vertical diffusion is not applied in the middle atmosphere to keep the sharp vertical shear in the QBO. The transport of chemical species employs a hybrid semiLagrangian transport scheme compatible with the continuity equation to satisfy the mass conservation. The chemistry module treats 36 long-lived species including 7 families and 15 short-lived species with 83 gas-phase reactions, 35 photochemical reactions, and 9 heterogeneous reactions on polar stratospheric clouds and sulfate aerosols.

The MRI-CCM was integrated under the B2 scenario of the second phase ChemistryClimate Model Validation Activity (CCMVal-2), i.e., REF-B2 [24], which specifies a timeevolving forcing by greenhouse gases (GHGs), ozone depleting substances (ODSs), and sea surface temperature (SST) and with fixed solar minimum and background aerosol conditions in the stratosphere. The integration was performed for about 50 years from 1970 until 2020 and referred to as a standard run (ST run), in which the QBO was realistically simulated in zonal wind and ozone [21]. In addition to the standard run, experiment runs were performed by changing the intensity of the radiative feedback of ozone. The ozone abundance $\mathrm{O}_{3}{ }^{(\mathrm{chem})}$ calculated as a prognostic variable in the chemistry module was modified (i.e., increased or decreased), and after that, the resultant ozone abundance $\mathrm{O}_{3}{ }^{\text {(dyn) }}$ was transferred to the dynamics module, wherein $\mathrm{O}_{3}(\mathrm{dyn})$ was used in the radiative process. The modification of ozone was made only in the tropical stratosphere (100-10 hPa), outside of which there was no modification. The relation between the two ozone abundances is represented with a latitudinal shape function $F(\theta)$, an altitudinal shape function $G(P)$, and a modulation constant $\delta$ as

$$
\begin{gathered}
\mathrm{O}_{3}{ }^{(\text {dyn })}(\varphi, \theta, \mathrm{P})=\mathrm{O}_{3}{ }^{(\text {chem })}(\varphi, \theta, \mathrm{P})[1+\delta \cdot \mathrm{F}(\theta) \cdot \mathrm{G}(\mathrm{P})], \\
\left.\mathrm{F}(\theta)=\exp \left[\left(-\theta / \theta_{0}\right)^{2}\right)\right], \theta_{0}=15 \text { degrees, } \\
\mathrm{G}(\mathrm{P})=1.0, \text { for } 100 \leq \mathrm{P} \leq 10, \\
\max [0,(\ln (\mathrm{P})-\ln (7)) /(\ln (10)-\ln (7))], \text { for } 10<\mathrm{P}, \\
\max [0,(\ln (120)-\ln (\mathrm{P})) /(\ln (120)-\ln (100))], \text { for } 120<\mathrm{P},
\end{gathered}
$$

where $\varphi, \theta$, and $\mathrm{P}$ represent the longitude, latitude, and pressure (hPa), respectively. In brief, $F(\theta)$ (Equation (2)) is a Gaussian function with an e-folging latitude $\theta_{0}$, and $G(P)$ (Equation (3)) is a smooth boxcar function, which has a flat value of 1.0 between 100 and $10 \mathrm{hPa}$ and tapering slopes decreasing to 0.0 , respectively, from 10 to $7 \mathrm{hPa}$ and from 100 to $120 \mathrm{hPa}$. The use of the shape functions guarantees that $\mathrm{O}_{3}(\mathrm{dyn})$ is smoothly and gradually varied to $\mathrm{O}_{3}{ }^{(\mathrm{chem})}$ with changes in latitude and pressure, and $\mathrm{O}_{3}{ }^{(\mathrm{dyn})}$ is virtually identical to $\mathrm{O}_{3}{ }^{\text {(chem) }}$ outside the $\mathrm{QBO}$ region (i.e., the tropical stratosphere). Hence, the direct effect of changing the ozone radiative feedback works only in the tropical stratosphere, accordingly. The ST run corresponds to $\delta=0$, i.e., $\mathrm{O}_{3}{ }^{(\mathrm{dyn})} \equiv \mathrm{O}_{3}{ }^{(\mathrm{chem})}$.

Five experiment runs were made with the modulation constants $\delta=-0.4,-0.2,-0.1$, +0.1 , and +0.2 , respectively, and these experiment runs were referred to as $L, N, M, Q$, and $\mathrm{P}$ run, respectively. The $\mathrm{L}, \mathrm{N}$, and $\mathrm{M}$ runs mean that $\mathrm{O}_{3}{ }^{(\mathrm{dyn})}$ is decreased from $\mathrm{O}_{3}{ }^{\text {(chem) }}$ by $40 \%, 20 \%$, and $10 \%$, respectively, in the tropical stratosphere, while in the $\mathrm{Q}$ and $\mathrm{P}$ runs, $\mathrm{O}_{3}(\mathrm{dyn})$ is increased by $10 \%$ and $20 \%$, respectively. The CCM was integrated for about 20 years from 1970 to 1990 for each modulation constant in the experiment runs, the integration period of which was much shorter than that of the standard run of about 50 years.

\section{Results}

\subsection{Zonal Wind and Temperature}

Figure 1 depicts the time-height cross-sections of zonal-mean zonal wind anomalies averaged between $10^{\circ} \mathrm{S}$ and $10^{\circ} \mathrm{N}$ in the tropical stratosphere (100-5 hPa) for the $\mathrm{P}$ $(+20 \%)$, ST $(0 \%)$, and N $(-20 \%)$ runs, and ERA-40 [25] for about 10 years from 1975 to 1985. Anomalies mean the deviations from the annual cycle, i.e., climatological monthly value 
is subtracted for each month. The ST run simulated a $\mathrm{QBO}$ of about a 28 -month period and of about $18 \mathrm{~ms}^{-1}$ amplitude with stronger westerly shear $(\mathrm{du} / \mathrm{dz}>0)$ than easterly shear $(\mathrm{du} / \mathrm{dz}<0)$. The QBO period was simply calculated as an average period of the band-passed time series free of the annual and semi-annual components, rather than using the Fourier expansion. This is because different integration terms of $\sim 50$ and $\sim 20$ years, respectively, for the standard and experiment runs resulted in different spectral resolutions for the spectral analysis. Comparison between the ST run and ERA-40 reveals that the QBO is realistically reproduced, though the simulated amplitude is slightly $(\sim 10 \%)$ smaller than the observed amplitude. The QBO phases are different between them, because the $\mathrm{QBO}$ is a spontaneous internal oscillation.

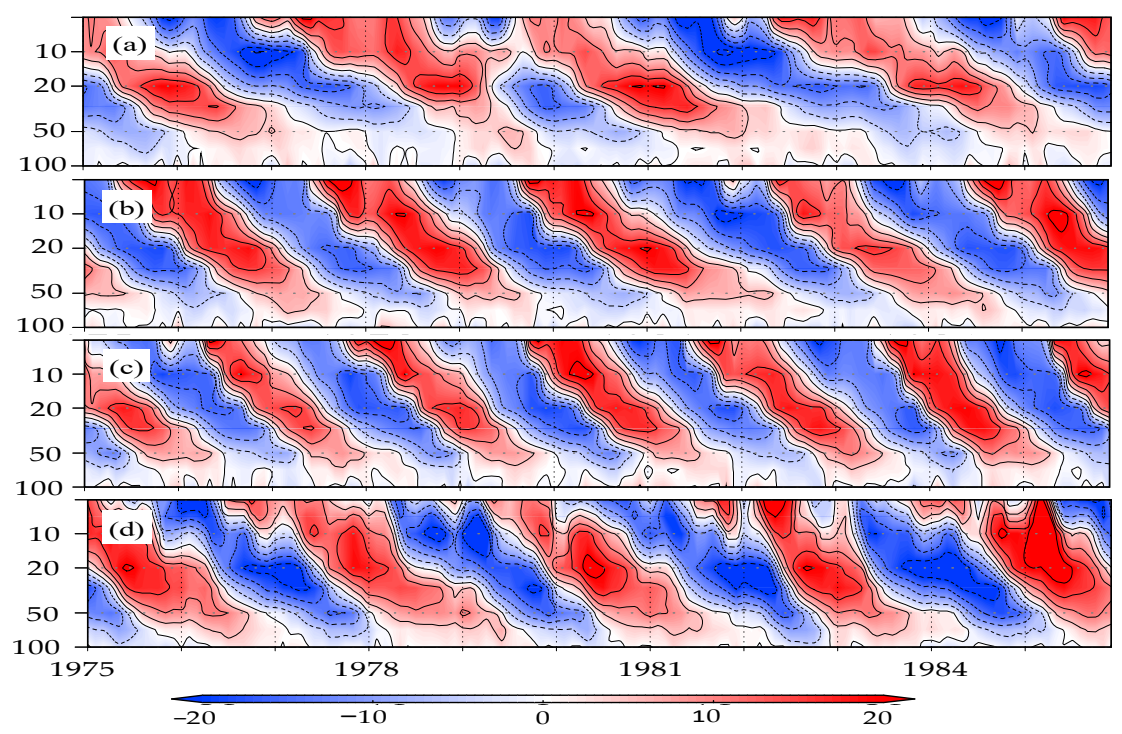

Figure 1. Time-height cross-sections of zonal-mean zonal wind anomalies $\left(\mathrm{ms}^{-1}\right)$ averaged between $10^{\circ} \mathrm{S}$ and $10^{\circ} \mathrm{N}$ in the tropical stratosphere $(100-5 \mathrm{hPa})$ for the (a) $\mathrm{P}(+20 \%),(\mathbf{b}) \mathrm{ST}(0 \%)$, and (c) $\mathrm{N}$ $(-20 \%)$ runs, and (d) ERA-40 from 1975 to 1985 . Contours interval is $5 \mathrm{~ms}^{-1}$.

Compared to the ST run, the $\mathrm{QBO}$ amplitude is nearly unchanged both in the $\mathrm{P}$ and $\mathrm{N}$ runs, while the QBO period is substantially prolonged in the P run ( 34-month) but abridged in the $\mathrm{N}$ run ( 22-month). Similarly, the elongation of the QBO period occurred in the $\mathrm{Q}(+10 \%)$ run, and the shortening took place in the $\mathrm{M}(-10 \%)$ and $\mathrm{L}(-40 \%)$ runs, as displayed in Figure 2, in which the QBO periods are about 31, 24, and 17 months, respectively, for the $Q, M$, and $L$ runs. These results in Figures 1 and 2 indicate that the QBO period varies with the magnitude of the ozone feedback through the solar heating, because the differences among the experiment runs and the standard run are only those in the modulation constant for ozone in the dynamics (Equation (1)). In other words, as ozone in the dynamics was increased from $-40 \%$ through $-20 \%,-10 \%, 0 \%$, and $+10 \%$ to $+20 \%$, the QBO period was getting longer in order of about $17,22,24,28,31$, and 34 months. On the other hand, the amplitude of the QBO remained approximately a similar value $\left(\sim 18 \mathrm{~m} \cdot \mathrm{s}^{-1}\right)$ for all the runs except for the $\mathrm{L}$ run.

Of the five experiment runs there occurred a peculiar time evolution (disruption) of the QBO in the P run in 1979 between 20 and $10 \mathrm{hPa}$, as depicted in Figure 1. The normal downward propagation of the easterly phase suspended, and the westerly phase anomalously developed upward from about 20 to $10 \mathrm{hPa}$. A very similar abnormal behavior of the QBO (suspension of the easterly phase descending) took place in the observation data from about 30 to $15 \mathrm{hPa}$ in 2015-2016 [26]. Also in the Q run, a peculiar time evolution occurred, wherein not a suspension but an abnormal stalling of the westerly phase continued from the late 1978 to the end of 1979 between 20 and $10 \mathrm{hPa}$. As a result, there occurred a very long duration of the westerly phase in the upper stratosphere above $20 \mathrm{hPa}$ and a similar long period of the easterly phase around $30 \mathrm{hPa}$ (Figure 2). 


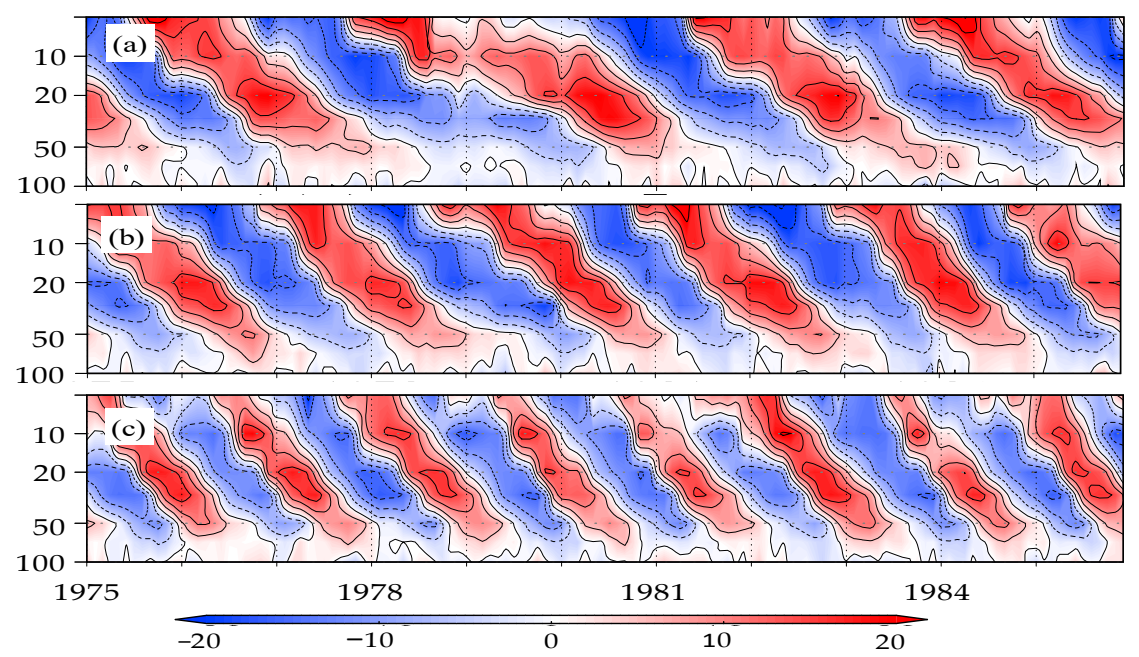

Figure 2. Time-height cross-sections of zonal-mean zonal wind anomalies $\left(\mathrm{ms}^{-1}\right)$ averaged between $10^{\circ} \mathrm{S}$ and $10^{\circ} \mathrm{N}$ in the tropical stratosphere $(100-5 \mathrm{hPa})$ for the (a) $\mathrm{Q}(+10 \%),(\mathbf{b}) \mathrm{M}(-10 \%)$, and (c) $\mathrm{L}$ $(-40 \%)$ runs from 1975 to 1985 . Contours interval is $5 \mathrm{~ms}^{-1}$.

Henceforth, only the results for the P, ST, and N runs are shown for simplicity unless otherwise specified. This is because the ozone increase effect in the $P$ and $Q$ runs can be qualitatively represented by the $P$ run, and the ozone decrease effect in the $\mathrm{M}, \mathrm{N}$, and $\mathrm{L}$ runs by the $\mathrm{N}$ run. Figure 3 exhibits the time-height cross-sections of zonal-mean temperature anomalies averaged between $10^{\circ} \mathrm{S}$ and $10^{\circ} \mathrm{N}$ in the tropical stratosphere $(100-5 \mathrm{hPa})$ for about 10 years from 1975 to 1985 . The positive (negative) temperature anomalies during the westerly (easterly) shear descent are of order $1.5^{\circ} \mathrm{C}$ in common across most of the runs. Namely, there are scarcely substantial differences in temperature as well as in zonalwind across the standard and experiments runs except for the L run. The westerly shear zone has positive temperature anomalies through the thermal wind balance, while there are negative temperature anomalies during the easterly shear descent. Since radiative relaxation in terrestrial wavelengths damps these positive and negative anomalies on a one- to two-week timescale, maintenance of the thermal wind balance requires adiabatic heating (cooling) by a residual mean circulation with sinking (rising) at the equator [27], so that positive temperature anomaly zones correspond to downdraft (residual mean vertical velocity $\overline{w^{*}}<0$ ) anomaly zones, while negative temperature anomaly zones correspond to updraft $\left(\overline{w^{*}}>0\right)$ anomaly zones, as will be shown later.

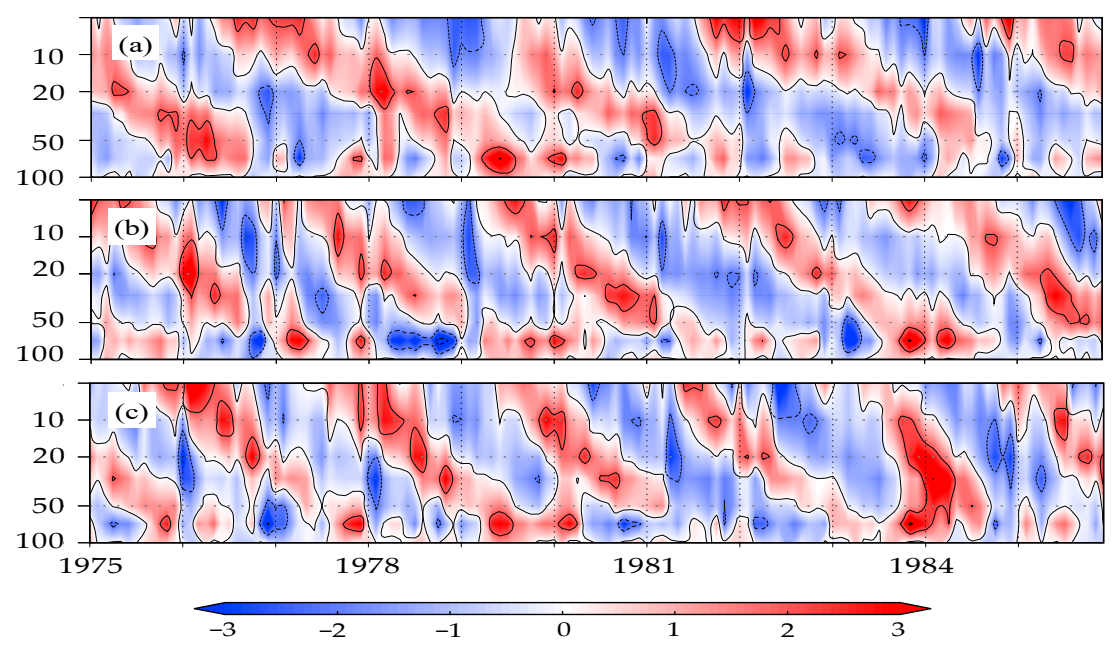

Figure 3. Time-height cross-sections of zonal-mean temperature anomalies (K) averaged between $10^{\circ} \mathrm{S}$ and $10^{\circ} \mathrm{N}$ in the tropical stratosphere for the (a) P, (b) ST, and (c) N runs from 1975 to 1985. Contours interval is $2 \mathrm{~K}$. 


\subsection{Vertical Veocity, Ozone and Radiative Heating}

Figure 4 exhibits the time-height cross-sections of residual mean vertical velocity anomalies $\left(\overline{w^{*}}\right)$ averaged between $10^{\circ} \mathrm{S}$ and $10^{\circ} \mathrm{N}$ in the tropical stratosphere $(100-5 \mathrm{hPa})$ for about 10 years from 1975 to 1985 . Positive and negative values correspond to the easterly and westerly shear zones, respectively. The anomalies are nearly the same magnitude for most of the runs, and they are of order $0.4 \cdot 10^{-4} \mathrm{~ms}^{-1}$ in the lower stratosphere and $2 \cdot 10^{-4} \mathrm{~ms}^{-1}$ in the upper stratosphere, being in good agreement with those based on observation data $[28,29]$. The magnitude of negative $\overline{w^{*}}$ is slightly stronger during the westerly shear descent than that of positive $\overline{w^{*}}$ during the easterly shear descent below $20 \mathrm{hPa}$, stemming from the larger value of the westerly shear.

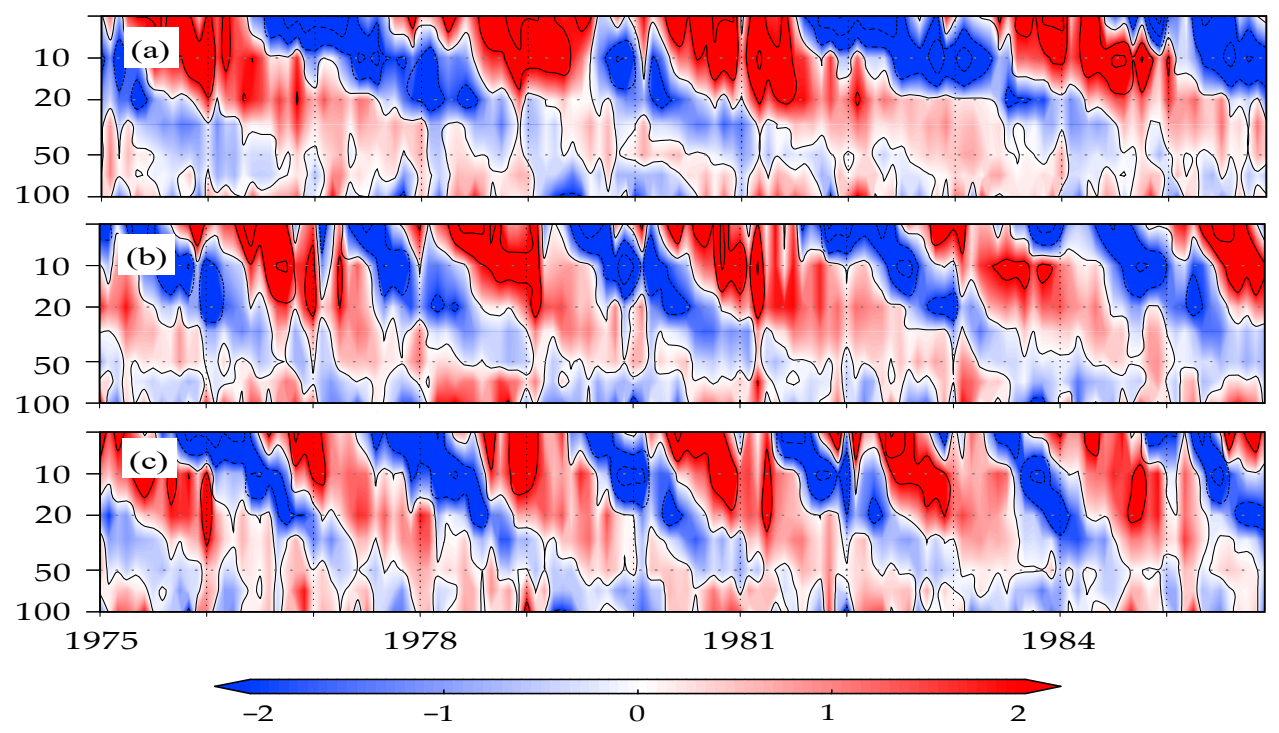

Figure 4. Time-height cross-sections of residual mean vertical velocity anomalies averaged between $10^{\circ} \mathrm{S}$ and $10^{\circ} \mathrm{N}$ in the tropical stratosphere for the (a) P, (b) ST, and (c) N runs from 1975 to 1985. Units of the color bar scale are in $10^{-4} \mathrm{~ms}^{-1}$, and the contours interval is $2 \times 10^{-4} \mathrm{~ms}^{-1}$.

In the observed ozone $\mathrm{QBO}$, there is a phase transition at around $28 \mathrm{~km}(\sim 18 \mathrm{hPa})$, i.e., ozone anomalies above and below the phase transition are out of phase to each other [30-32]. The phase transition comes from the strong dependence of the chemical lifetime of ozone on the altitude. The chemical lifetime of ozone is much shorter (longer) than the ozone transport timescale in the upper (lower) stratosphere. Therefore, photochemistry controls the ozone QBO above the transition altitude, while dynamics (transport) controls ozone below the transition altitude. As a result of the phase transition, the ozone QBO exhibits a dogleg-shaped pattern, being very different from the slanting stripe pattern of the zonal wind QBO. MRI-CCM realistically reproduced the ozone $\mathrm{QBO}$ including the phase transition and proved that both $\mathrm{NO}_{\mathrm{x}}$ and adiabatic heating due to the residual mean vertical motion were the dominant drivers in the photochemistry control [21].

Figure 5 displays the time-height cross-sections of zonal-mean ozone $\mathrm{O}_{3}{ }^{(\mathrm{dyn})}$ anomalies in the dynamics averaged between $10^{\circ} \mathrm{S}$ and $10^{\circ} \mathrm{N}$ in the tropical stratosphere $(100-5 \mathrm{hPa})$ from 1975 to 1985 . The amplitude of $\mathrm{O}_{3}{ }^{(\mathrm{dyn})}$ anomalies is largest in the $\mathrm{P}$ run and smallest in the $\mathrm{N}$ run above $20 \mathrm{hPa}$, whereas the differences in the three runs are much smaller, below $30 \mathrm{hPa}$. This indicates that the amplitude of $\mathrm{O}_{3}{ }^{(\mathrm{chem})}$ anomalies below $30 \mathrm{hPa}$ is much larger in the $\mathrm{N}$ run than in the ST and P runs. It should be noted that $\mathrm{O}_{3}(\mathrm{dyn})$ anomalies in Figure $4 \mathrm{~b}$ represent $\mathrm{O}_{3}{ }^{(\mathrm{chem})}$ anomalies, because no modification was made for ozone in the ST run, as stated above. In the dynamics control below about $20 \mathrm{hPa}$, positive ozone anomalies are slightly larger during the westerly shear descent than negative ozone anomalies during the easterly shear descent. 

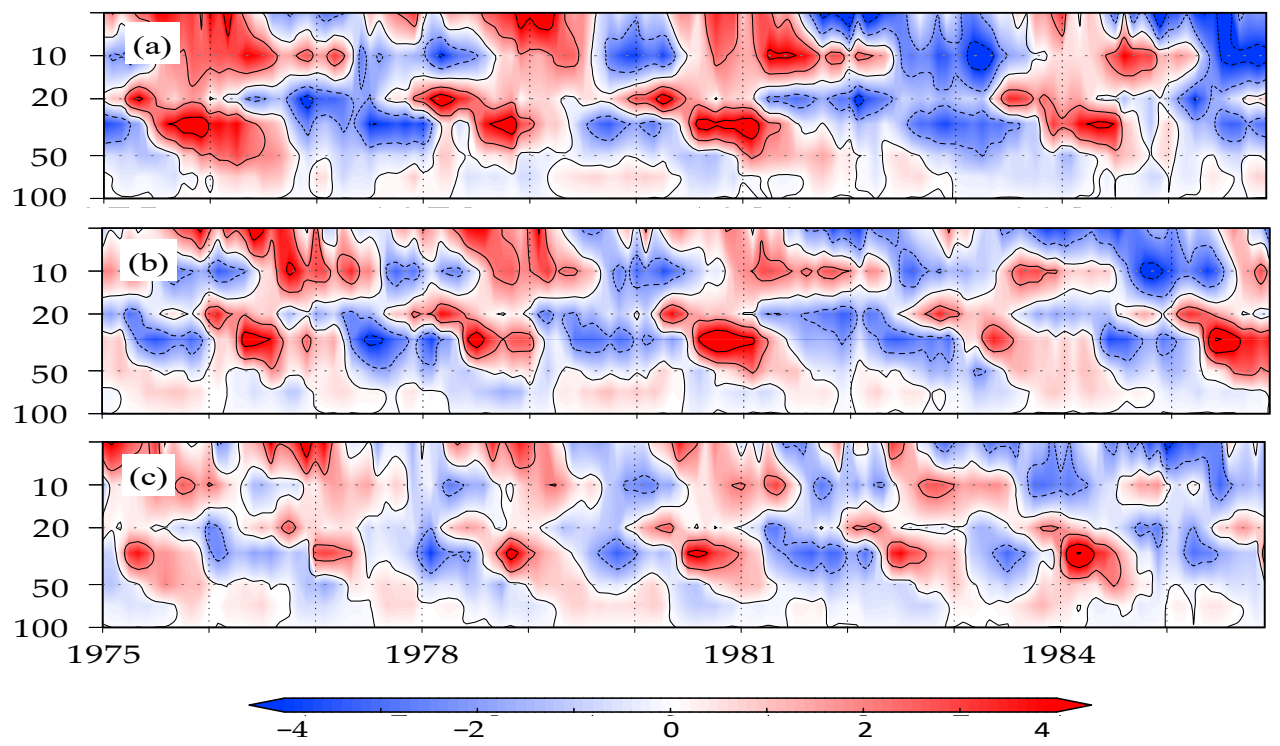

Figure 5. Time-height cross-sections of zonal-mean ozone in the dynamics $\mathrm{O}_{3}{ }^{(\mathrm{dyn})}$ in the tropical stratosphere for the (a) $\mathrm{P},(\mathbf{b}) \mathrm{ST}$, and (c) N runs from 1975 to $1985 . \mathrm{O}_{3}(\mathrm{dyn})$ is an anomaly and averaged between $10^{\circ} \mathrm{S}$ and $10^{\circ} \mathrm{N}$. Units of the color bar scale are in $0.1 \mathrm{ppmv}$, and the contours interval is 0.2 ppmv.

Figure 6 exhibits the time-height cross-sections of zonal-mean solar heating anomalies averaged between $10^{\circ} \mathrm{S}$ and $10^{\circ} \mathrm{N}$ in the tropical stratosphere (100-5 hPa) from 1975 to 1985. The westerly shear descent brought about negative solar heating anomalies in the photochemistry control above $\sim 20 \mathrm{hPa}$ and positive solar heating anomalies in the dynamics control below. For the easterly shear descent, the opposite anomalies occurred. The solar heating anomalies in the ST run are about $2 \mathrm{~K} \cdot \mathrm{mon}^{-1}$ in the dynamics control 20-30 hPa with slightly larger anomalies during the westerly shear descent than during the easterly shear descent, in accord with the ozone anomalies. In the photochemistry control at about $10 \mathrm{hPa}$, the solar heating anomalies are of similar magnitude to those at $20 \mathrm{hPa}$ with reverted polarities. The magnitudes of the solar heating anomalies show good correspondence to those of the ozone anomalies $\mathrm{O}_{3}{ }^{(\mathrm{dyn})}$ (Figure 5) in the P, ST, and N runs as well as in the Q, M, and L runs.
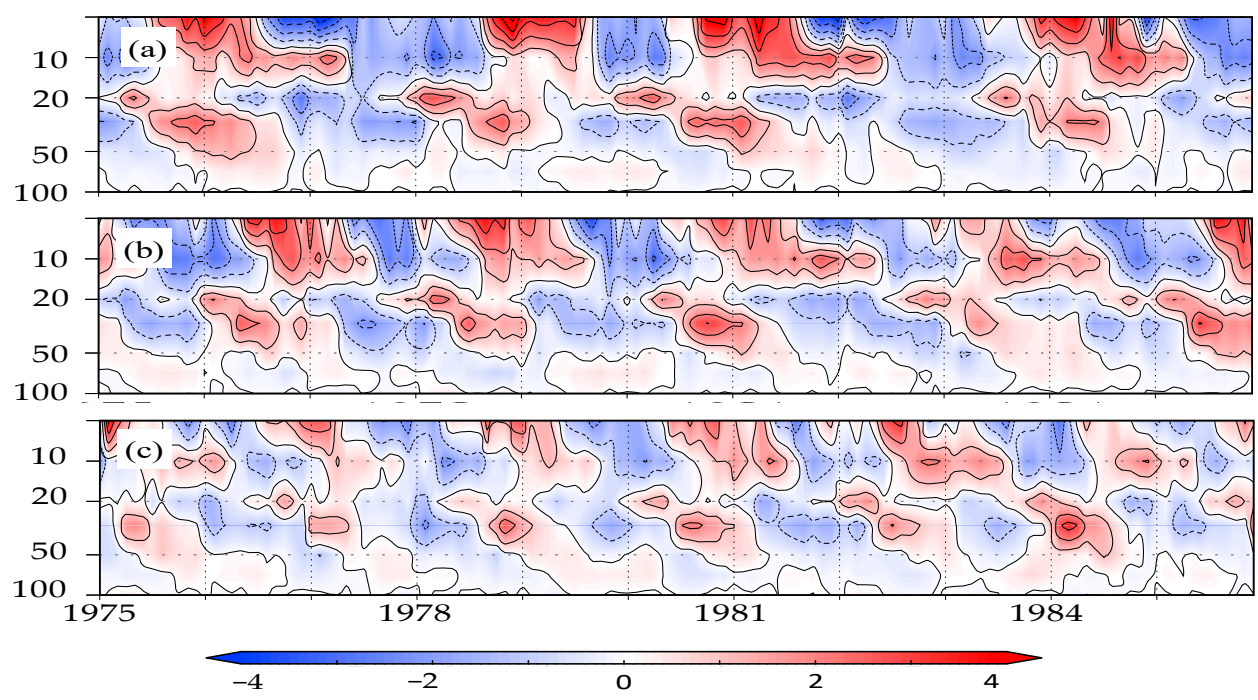

Figure 6. Time-height cross-sections of zonal-mean solar heating anomalies averaged between $10^{\circ} \mathrm{S}$ and $10^{\circ} \mathrm{N}$ in the tropical stratosphere for the (a) P, (b) ST, and (c) N runs from 1975 to 1985. Units of the color bar scale are in $\mathrm{K} \mathrm{mon}^{-1}$, and the contours interval is $1 \mathrm{~K} \mathrm{mon}^{-1}$. 
Terrestrial heating anomalies (Figure 7) are negative in the westerly shear zone, where warming anomalies are held through the thermal wind balance. On the other hand, terrestrial heating anomalies are positive in the easterly shear zone accompanied by cold anomalies. In addition, since the descent of the shear zone induces solar heating anomalies through the vertical transport of ozone and $\mathrm{NO}_{\mathrm{x}}$, and adiabatic temperature changes, terrestrial heating anomalies approximately coincide with solar heating anomalies with respect to their zones. However, they are in-phase in the photochemistry control above about $20 \mathrm{hPa}$, while they are out of phase in the dynamics control below. The amplitude of terrestrial heating anomalies is two or three times as large as that of solar heating anomalies, similarly to the previous study [19]. As a result, radiative (solar + terrestrial) heating anomalies (not shown) exhibit a similar pattern to terrestrial heating anomalies.

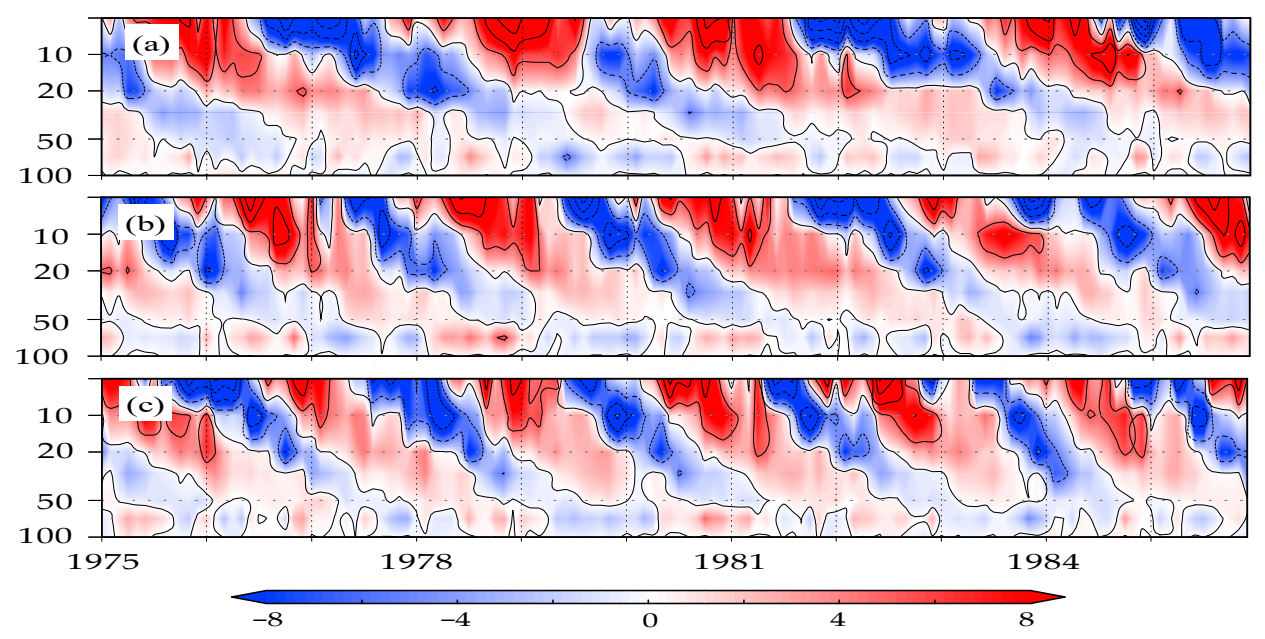

Figure 7. Time-height cross-sections of zonal-mean terrestrial heating anomalies averaged between $10^{\circ} \mathrm{S}$ and $10^{\circ} \mathrm{N}$ in the tropical stratosphere for the (a) P, (b) ST, and (c) N runs from 1975 to 1985. Units of the color bar scale are in $\mathrm{K} \mathrm{mon}^{-1}$, and the contours interval is $5 \mathrm{~K} \mathrm{mon}^{-1}$.

\subsection{Latitudinal Extent of the Meridional Circulation}

Next, the effect of the ozone feedback on the meridional extent of the QBO is examined. Figure 8 displays the time-latitude cross-sections of the zonal-mean zonal wind anomalies between $30^{\circ} \mathrm{S}$ and $30^{\circ} \mathrm{N}$ at $20 \mathrm{hPa}$ from 1975 to 1985 . Aside from the prominent differences in the QBO periods, the three runs show the following common features for the zonal wind anomalies: the amplitudes are about $18 \mathrm{~ms}^{-1}$, and the meridional width evaluated from zero-wind latitudes is approximately $40^{\circ}$ from about $20^{\circ} \mathrm{S}$ to $20^{\circ} \mathrm{N}$. In addition, the temporal tendencies during the phase reversal are commonly larger in the three runs from easterly to westerly than from westerly to easterly, indicating stronger westerly vertical shear during the shear zone descent. The QBO disruption in 1979 of the P run appears as abnormally short westerly and easterly durations ( 1 year) from early 1978 to late 1981, resulting in a short QBO cycle of $\sim 2$ years.

Figure 9 exhibits the time-latitude cross-sections of residual mean vertical velocity anomalies $\overline{w^{*}}$ between $30^{\circ} \mathrm{S}$ and $30^{\circ} \mathrm{N}$ at $20 \mathrm{hPa}$ from 1975 to 1985 . The amplitude of $\overline{w^{*}}$ is of a similar order across the three runs as in the amplitude of zonal-wind. The value of $\overline{w^{*}}$ at the equator maximizes during the phase reversal of zonal-wind from westerly to easterly and minimizes during the phase reversal from easterly to westerly, meaning that $\overline{w^{*}}$ is retarded by a quarter cycle from zonal-wind. The meridional width of $\overline{w^{*}}$ is nearly $20^{\circ}$ from about $10^{\circ} \mathrm{S}$ to $10^{\circ} \mathrm{N}$, which is about half of the zonal-wind meridional width in Figure 8. Also $\overline{w^{*}}$ in the equatorial region is comprised of much finer temporal-spatial components compared to zonal-wind. This is because the steep vertical shear of zonalwind, which is related to strong vertical velocity, is confined to the narrow zone near the zero-wind (Figure 1). Further, negative $\overline{w^{*}}$ (downdraft) is larger and more well-organized than positive $\overline{w^{*}}$ (updraft) in the three runs. 


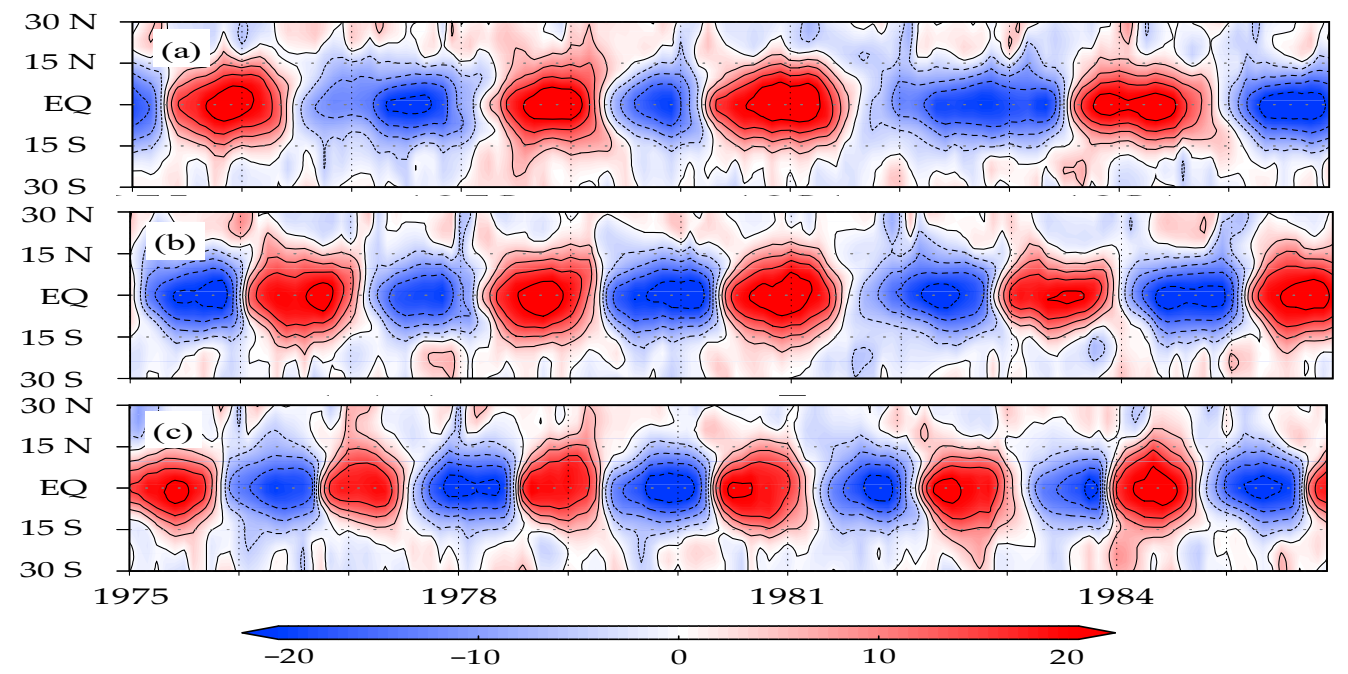

Figure 8. Time-latitude cross-sections of zonal-mean zonal wind anomalies at $20 \mathrm{hPa}$ for the (a) P, (b) ST, and (c) N runs from 1975 to 1985 . Units of the color bar scale are in $\mathrm{ms}^{-1}$, and the contours interval is $5 \mathrm{~ms}^{-1}$.

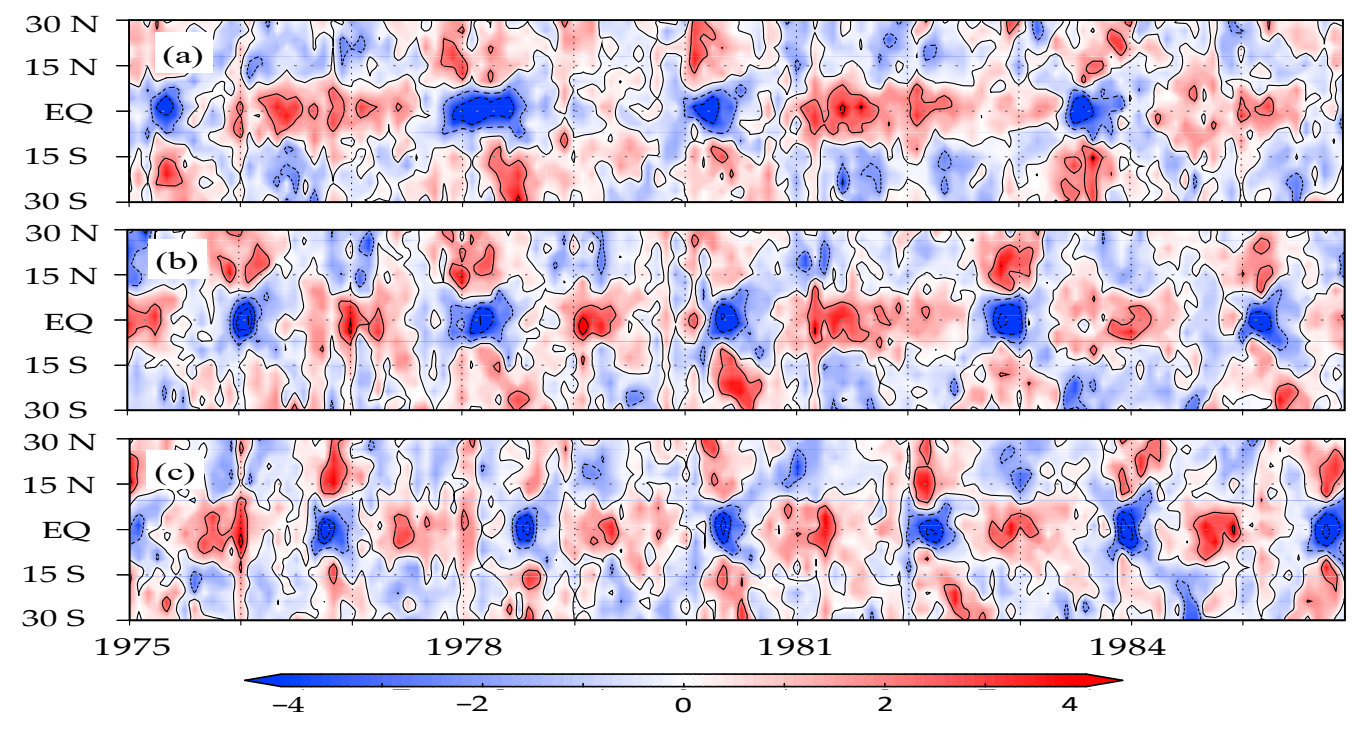

Figure 9. Time-latitude cross-sections of residual mean vertical velocity anomalies at $20 \mathrm{hPa}$ for the (a) P, (b) ST, and (c) N runs from 1975 to 1985. Units of the color bar scale and the contours interval are $2 \times 10^{-4} \mathrm{~ms}^{-1}$.

Figure 10 exhibits the time-latitude cross-sections of residual mean meridional velocity anomalies $\overline{v^{*}}$ between $30^{\circ} \mathrm{S}$ and $30^{\circ} \mathrm{N}$ at $20 \mathrm{hPa}$ from 1975 to 1985 . The meridional width of $\overline{v^{*}}$ is estimated about $50^{\circ}$ between $25^{\circ} \mathrm{S}$ and $25^{\circ} \mathrm{N}$, slightly wider than that of zonal wind, though its zero-wind latitudes are not necessarily determined. The temporal-spatial pattern of $v^{*}$ shows quadruple finer structures in the three runs during the phase reversal of zonal-wind. This fine structure is based on the temporal and spatial features that $\overline{v^{*}}$ temporally reverts its direction in the vicinity of the phase reversal of zonal-wind, and $\overline{v^{*}}$ is spatially antisymmetric with respect to the equator. 


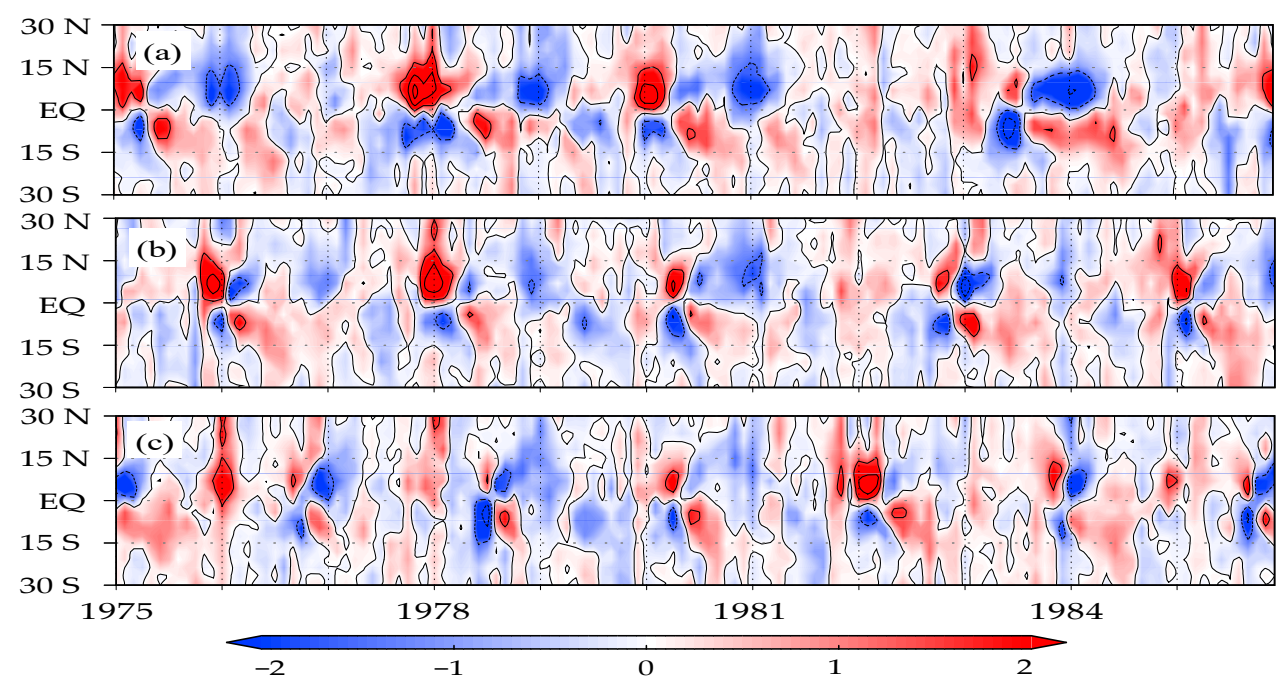

Figure 10. Time-latitude cross-sections of residual mean meridional velocity anomalies at $20 \mathrm{hPa}$ for the (a) P, (b) ST, and (c) N runs from 1975 to 1985 . Units of the color bar scale are $10^{-1} \mathrm{~ms}^{-1}$, and the contours interval is $1.5 \times 10^{-1} \mathrm{~ms}^{-1}$.

\section{Discussion}

The standard and experiment runs demonstrated that the ozone feedback through solar radiation had crucial impacts on the QBO period with slight effects on the QBO amplitude. The result is thus summarized as that the QBO period is prolonged with the increase in the ozone feedback and conversely shortened with the decrease in the ozone feedback. This relation between the QBO period and the ozone feedback is compatible with the past CCM and GCM experiments [18-20]. However, it is difficult to clarify the pathway from the ozone feedback to the changes in the QBO period. Indeed, the ozone solar heating is known to be related to residual mean vertical velocity in the governing equation of the QBO [12,27], but to examine how perturbations in the ozone solar heating affect the $\mathrm{QBO}$ is difficult within the framework of CCMs. This is because most variables in CCMs are internally adjusted through complicated feedback loops.

The driving forces of the $\mathrm{QBO}$ in the MRI-CCM are due to resolved waves propagating from the troposphere and parameterized gravity waves launched at the lowest level [33]. The former forcing is represented by the Eliassen-Palm flux divergence (EPD), and the latter is referred to as gravity-wave forcing (GWF). Figure 11 shows the time series of the QBO components of zonal-mean zonal wind, EPD, GWF, and combined forcing (EPD+GWF) at $20 \mathrm{hPa}$ from 1975 to 1985, in which a band-pass Lanczos filter [34] was applied to derive the QBO components. The QBO amplitude of zonal-wind is about $18 \mathrm{~ms}^{-1}$ for the ST and $\mathrm{N}$ runs, while the P run shows a slightly smaller amplitude. EPD and GWF are nearly of the same amplitude and in-phase in each run. Among the three runs, the amplitudes of EPD and GWF are of similar magnitude to the ST and N runs, while they are smaller in the P run. The combined forcing EPD+GWF, which is advanced by a quarter cycle to zonal-wind, shows an amplitude of about $0.25 \mathrm{~ms}^{-1}$ day $^{-1}$ for the ST and N runs and of about $0.20 \mathrm{~ms}^{-1}$ day $^{-1}$ for the P run. Accordingly, the magnitudes of the combined forcing amplitudes are qualitatively consistent with the magnitudes of the zonal-wind amplitude.

Residual mean circulation also contributes to the acceleration of zonal wind. Figure 12 depicts zonal-mean zonal winds of the QBO component and residual mean vertical velocity anomalies of 7-month moving average at $20 \mathrm{hPa}$ for the P, ST, and $\mathrm{N}$ runs from 1975 to 1985. The amplitudes of $\overline{w^{*}}$ in the three runs are, on average, very similar values of about $20 \times 10^{-5} \mathrm{~ms}^{-1}$, indicating that the strengths of the residual mean circulation associated with the QBO are also very similar among the three runs. 


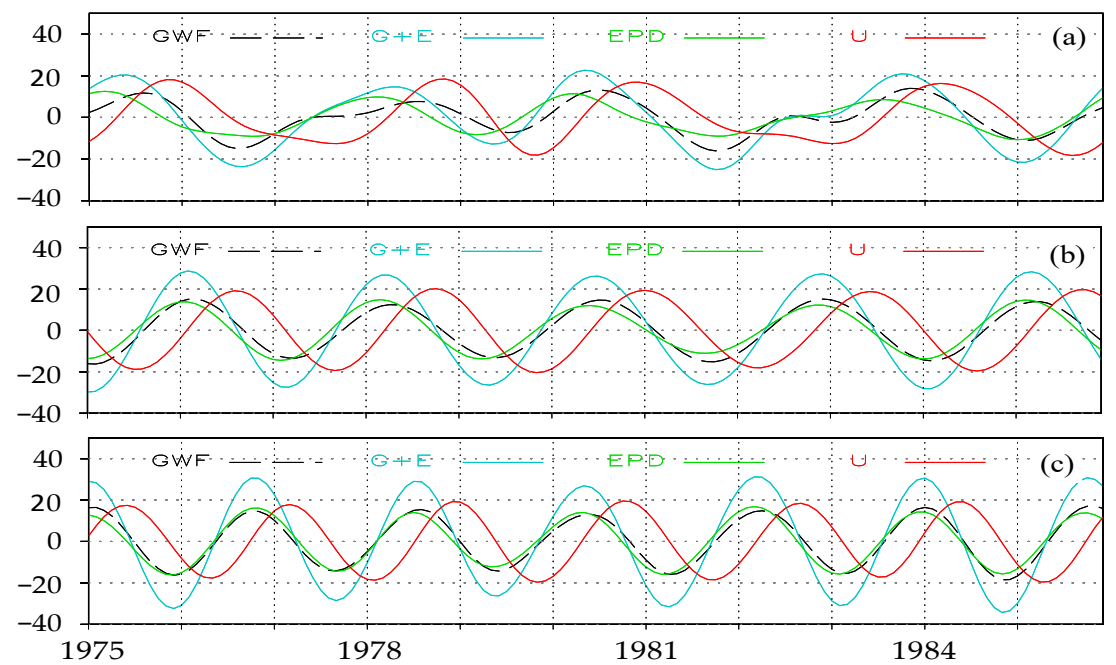

Figure 11. QBO components of zonal-mean zonal wind (red) and forcings (parameterized gravity wave forcing (GWF, black dash-line), resolved wave forcing (EPD, light green), and combined forcing $(\mathrm{G}+\mathrm{E}, \mathrm{cyan}))$ at $20 \mathrm{hPa}$ for the (a) P, (b) ST, and (c) N runs from 1975 to 1985 . All the quantities are averaged between $10^{\circ} \mathrm{S}$ and $10^{\circ} \mathrm{N}$. Units are in $\mathrm{ms}^{-1}$ for wind, and $10^{-2} \mathrm{~ms}^{-1} \mathrm{day}^{-1}$ for forcings.

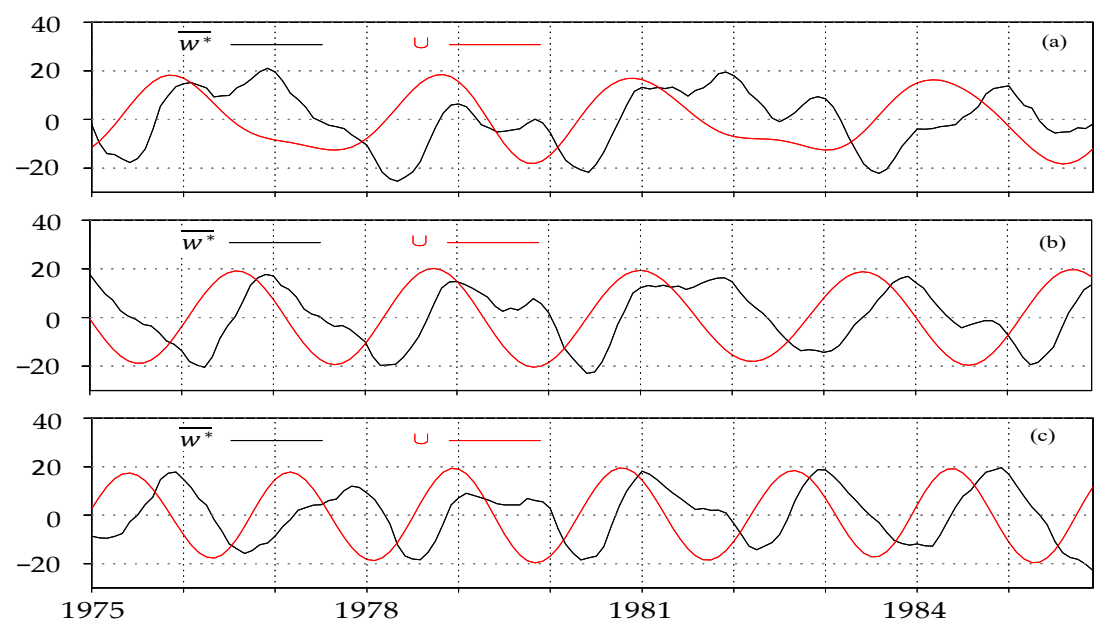

Figure 12. Zonal-mean zonal winds (red) and residual mean vertical velocity anomalies $\left(\overline{w^{*}}\right)$ (black) at $20 \mathrm{hPa}$ for the (a) P, (b) ST, and (c) N runs from 1975 to 1985. All the quantities are averaged between $10^{\circ} \mathrm{S}$ and $10^{\circ} \mathrm{N}$. Units are in $\mathrm{ms}^{-1}$ for zonal wind and $10^{-5} \mathrm{~ms}^{-1}$ for $\overline{w^{*}}$.

On the other hand, climatological values (annual averages for 1975-1985) of residual mean vertical velocity $\overline{w^{*}(\mathrm{clim})}$ are systematically different above $50 \mathrm{hPa}$ among the six runs as tabulated in Table 1, while there is virtually no difference below $70 \mathrm{hPa}$. This indicates that climatological (background) upwelling above $50 \mathrm{hPa}$ monotonically varies with the strength of the ozone feedback. The reason why background upwelling variations appear only above $50 \mathrm{hPa}$ is currently unknown.

Table 1. Climatological values of residual mean vertical velocity with interannual variations.

\begin{tabular}{ccccccc}
\hline $\begin{array}{c}\text { Altitude } \\
\mathbf{( h P a )}\end{array}$ & $\mathbf{P ( + 2 0 \% )}$ & $\mathbf{Q ( + 1 0 \% )}$ & $\mathbf{S T}(\mathbf{0} \%)$ & $\mathbf{M}(-\mathbf{1 0} \%)$ & $\mathbf{N}(-\mathbf{2 0} \%)$ & $\mathbf{L}(-\mathbf{4 0} \%)$ \\
\hline 10 & $62 \pm 13$ & $57 \pm 13$ & $51 \pm 9$ & $42 \pm 10$ & $39 \pm 7$ & $20 \pm 2$ \\
20 & $41 \pm 9$ & $39 \pm 10$ & $36 \pm 7$ & $33 \pm 9$ & $29 \pm 6$ & $19 \pm 4$ \\
30 & $36 \pm 4$ & $33 \pm 4$ & $30 \pm 5$ & $28 \pm 4$ & $25 \pm 3$ & $18 \pm 2$ \\
\hline
\end{tabular}

Values are averaged between $10^{\circ} \mathrm{S}$ and $10^{\circ} \mathrm{N}$, and unit is $10^{-5} \mathrm{~ms}^{-1}$. Interannual variations are evaluated from detrended data. 
Table 2 shows the comparison of the $\mathrm{QBO}$ periods and the $\mathrm{QBO}$ amplitudes of zonalwind and temperature at $20 \mathrm{hPa}$, and ozone at 30,20 , and $10 \mathrm{hPa}$ in the standard and experiment runs. The QBO amplitudes of zonal-wind are similar values of $16-19 \mathrm{~ms}^{-1}$, except for a substantially smaller value of $12 \mathrm{~ms}^{-1}$ in the $\mathrm{L}$ run. This indicates that the QBO amplitudes of zonal-wind slightly depend on the magnitude of the ozone feedback for changes in ozone less than $20 \%$. Consistent with the zonal-wind, the QBO amplitudes of temperature are also similar values of $1.4-1.7^{\circ} \mathrm{C}$ for the $\mathrm{P}, \mathrm{ST}, \mathrm{M}$, and $\mathrm{N}$ runs and smaller values of $1.2-1.1^{\circ} \mathrm{C}$ for the $\mathrm{Q}$ and $\mathrm{L}$ runs. Therefore, the impact on the $\mathrm{QBO}$ amplitudes was approximately very small for up to $20 \%$ change in ozone, while the $40 \%$ decrease in ozone had a certain influence.

Table 2. Average QBO periods and amplitudes of wind, temperature, and ozone for the six runs.

\begin{tabular}{ccccccc}
\hline & $\mathbf{P ( + 2 0 \% )}$ & $\mathbf{Q}(+\mathbf{1 0} \%)$ & $\mathbf{S T}(\mathbf{0} \%)$ & $\mathbf{M}(-\mathbf{1 0} \%)$ & $\mathbf{N}(-\mathbf{2 0} \%)$ & $\mathbf{L}(-\mathbf{4 0} \%)$ \\
\hline$\tau(\mathrm{mon})$ & 34 & 31 & 28 & 22 & 21 & 17 \\
$\mathrm{u}\left(\mathrm{ms}^{-1}\right)$ & 16 & 16 & 18 & 19 & 18 & 12 \\
$\mathrm{~T}\left({ }^{\circ} \mathrm{C}\right)$ & 1.4 & 1.2 & 1.5 & 1.6 & 1.7 & 1.1 \\
$\mathrm{O}_{3}(10 \mathrm{hPa})$ & 0.23 & 0.28 & 0.26 & 0.24 & 0.21 & 0.08 \\
$\mathrm{O}_{3}(20 \mathrm{hPa})$ & 0.19 & 0.19 & 0.20 & 0.17 & 0.16 & 0.07 \\
$\mathrm{O}_{3}(30 \mathrm{hPa})$ & 0.28 & 0.27 & 0.29 & 0.36 & 0.35 & 0.26 \\
\hline
\end{tabular}

Amplitude is calculated as a half of peak-to-peak value of the composite QBO component averaged between $10^{\circ} \mathrm{S}$ and $10^{\circ} \mathrm{N}$ at $20 \mathrm{hPa}$ for wind and temperature and at 30, 20, and $10 \mathrm{hPa}$ for ozone. The QBO component is derived by applying a band-pass Lanczos filter. Unit of ozone is ppmv.

The QBO amplitudes of ozone $\mathrm{O}_{3}{ }^{(\mathrm{chem})}$ maximizing at $\sim 30 \mathrm{hPa}$ are slightly smaller in the $\mathrm{P}$ and $\mathrm{Q}$ runs of positive $\delta$ than in the ST run, while they are significantly larger in the $\mathrm{M}$ and $\mathrm{N}$ runs of negative $\delta$ except for the $\mathrm{L}$ run. At 20 and $10 \mathrm{hPa}$, the differences among the runs are small except for the $\mathrm{L}$ run. On the other hand, the QBO period is much more crucially influenced than the QBO amplitude. In addition, the QBO period is prolonged monotonically with the increase in the ozone feedback from 17 months of the $\mathrm{L}(-40 \%)$ run through 28 months of the ST $(0 \%)$ run to 34 months of the P $(+20 \%)$ run.

\section{Conclusions}

As a consequence of CCM simulations modifying the intensity of radiative feedback of interactive ozone in the equatorial stratosphere $(100-10 \mathrm{hPa})$, the interactive ozone is demonstrated to have crucial effects on the dynamics of the $\mathrm{QBO}$ through radiation. Above all, the ozone feedback works most effectively on the change in the QBO period such that the weaker the ozone feedback, the shorter the QBO period with slight change in the QBO amplitude. In other words, the QBO period is forced to change so as to hold the QBO amplitude nearly unchanged, as manifested in the time series of the QBO major forcings of EPD and GWF and the residual mean vertical velocity. The crucial effects of the ozone feedback on the QBO confirm the close relationship between ozone and dynamics in the stratosphere and also imply that the interactive ozone is preferable for numerical models of seasonal forecast and future climate simulation in which the stratosphere plays a dominant role in longer timescales.

The reason why the QBO period is monotonically changed with the intensity of the ozone feedback was not identified, because the QBO major forcings were scarcely influenced. One plausible mechanism for this response of the QBO is the monotonic changes in the background upwelling $\overline{w^{*}(\operatorname{clim})}$ above the middle stratosphere of $50 \mathrm{hPa}$ such that stronger (weaker) background upwelling retards (advances) the downward propagation of zonal wind, resulting in the lengthening (shortening) of the QBO period. However, to address the mechanism of this response of the QBO is beyond the scope of this study using a CCM. Future studies using mechanistic models are more appropriate to scrutinize the mechanism because the feedback loops are flexibly designed and tuned without changing the model climate state. 
Funding: This research received no external funding.

Informed Consent Statement: Not applicable.

Data Availability Statement: The data presented in this study are available on request from the corresponding author.

Acknowledgments: The long-term simulations of MRI-CCM were performed with the supercomputer system (NEC SX-ACE) of the National Institute for Environmental Studies, Japan.

Conflicts of Interest: The authors declare no conflict of interest.

\section{References}

1. Dall'Amico, M.; Gray, L.J.; Rosenlof, K.H.; Scaife, A.A.; Shine, K.P.; Stott, P.A. Stratospheric temperature trends: Impact of ozone variability and the QBO. Clim. Dyn. 2010, 34, 381-398. [CrossRef]

2. Bushell, A.C.; Jackson, D.R.; Butchart, N.; Hardiman, S.C.; Hinton, T.J.; Osprey, S.M.; Gray, L.J. Sensitivity of GCM tropical middle atmosphere variability and climate to ozone and parameterized gravity wave changes. J. Geophys. Res. 2010, 115, D15101. [CrossRef]

3. Eyring, V.; Butchart, N.; Waugh, D.W.; Akiyoshi, H.; Austin, J.; Bekki, S.; Bodeker, G.E.; Boville, B.A.; Brühl, C.; Chipperfield, M.P.; et al. Assessment of temperature, trace species and ozone in chemistry-climate model simulations of the recent past. J. Geophys. Res. 2006, 111, D22308. [CrossRef]

4. $\quad$ Eyring, V.; Cionni, I.; Bodeker, G.E.; Charlton-Perez, A.J.; Kinnison, D.E.; Scinocca, J.F.; Waugh, D.W.; Akiyoshi, H.; Bekki, S.; Chipperfield, M.P.; et al. Multi-model assessment of stratospheric ozone return dates and ozone recovery in CCMVal-2 models. Atmos. Chem. Phys. 2010, 10, 9451-9472. [CrossRef]

5. Ebdon, R.A.; Veryard, R.G. Fluctuations in equatorial stratospheric winds. Nature 1961, 189, 791-793. [CrossRef]

6. Reed, R.J.; Campbell, W.J.; Rasmussen, L.A.; Rogers, D.G. Evidence of a downward-propagating, annual wind reversal in the equatorial stratosphere. J. Geophys. Res. 1961, 66, 813-818. [CrossRef]

7. Funk, J.P.; Garnham, G.L. Australian ozone observations and a suggested 24 month cycle. Tellus 1962, 14, 378-382. [CrossRef]

8. Ramanathan, K.R. Bi-annual variation of atmospheric ozone over the tropics. Q. J. R. Meteorol. Soc. 1963, 89, 540-542. [CrossRef]

9. Lindzen, R.S.; Holton, J.R. A theory of quasi-biennial oscillation. J. Atmos. Sci. 1968, 25, 1095-1107. [CrossRef]

10. Holton, J.R.; Lindzen, R.S. An updated theory for the quasi-biennial cycle of the tropical stratosphere. J. Atmos. Sci. 1972, 29, 1076-1080. [CrossRef]

11. Plumb, R.A.; Bell, R.C. A model of the quasi-biennial oscillation on an equatorial beta-plane. Q. J. R. Meteorol. Soc. 1982, 108, 335-352. [CrossRef]

12. Dunkerton, T.J. A two-dimensional model of the quasi-biennial oscillation. J. Atmos. Sci. 1985, 42, 1151-1160. [CrossRef]

13. Hasebe, F. Quasi-biennial oscillations of ozone and diabatic circulation in the equatorial stratosphere. J. Atmos. Sci. 1994, 51, 729-745. [CrossRef]

14. Li, D.; Shine, K.P.; Gray, L.J. The role of ozone-induced diabatic heating anomalies in the quasi-biennial oscillation. Q. J. R. Meteorol. Soc. 1995, 121, 937-943. [CrossRef]

15. Cordero, E.C.; Nathan, T.R. The influence of wave- and zonal mean-ozone feedbacks on the quasi-biennial oscillation. J. Atmos. Sci. 2000, 57, 3426-3442. [CrossRef]

16. Huang, T.Y.W. The impact of solar radiation on the quasi-biennial oscillation of ozone in the tropical stratosphere. Geophys. Res. Lett. 1996, 23, 3211-3214. [CrossRef]

17. Tanii, R.; Hasebe, F. Ozone feedback stabilizes the quasi-biennial oscillation against volcanic perturbations. Geophys. Res. Lett. 2002, 29, 1110. [CrossRef]

18. Butchart, N.; Scaife, A.A.; Austin, J.; Hare, S.H.E.; Knight, J.R. Quasi-biennial oscillation in ozone in a coupled chemistry-climate model. J. Geophys. Res. 2003, 108, 4486. [CrossRef]

19. Shibata, K.; Deushi, M. Radiative effect of ozone on the quasi-biennial oscillation in the equatorial stratosphere. Geophys. Res. Lett. 2005, 32, L24802. [CrossRef]

20. Tian, W.; Chipperfield, M.P.; Gray, L.J.; Zawodny, J.M. Quasi-biennial oscillation and tracer distributions in a coupled chemistryclimate model. J. Geophys. Res. 2006, 111, D20301. [CrossRef]

21. Shibata, K.; Lehmann, R. Partitioning of ozone loss pathways in the ozone quasi-biennial oscillation simulated by a chemistryclimate model. J. Meteorol. Soc. Jpn. 2020, 98, 615-636. [CrossRef]

22. Shibata, K.; Deushi, M. Simulation of the stratospheric circulation and ozone during the recent past (1980-2004) with the MRI chemistry-climate model. In CGER's Supercomputer Monograph Report; National Institute for Environmental Studies: Tsukuba, Japan, 2008; Volume 13, 154p.

23. Hines, C.O. Doppler-spread parameterization of gravity-wave momentum deposition in the middle atmosphere. Part 2: Broad and quasi monochromatic spectra, and implementation. J. Atmos. Sol.-Terr. Phys. 1997, 59, 387-400. [CrossRef]

24. Morgenstern, O.; Giorgetta, M.; Shibata, K. Chemistry Climate Models and Scenarios. 2010. Available online: https:/ /library. wmo.int/index.php?lvl=notice_display\&id=17\#.YP0YRDpUuhd (accessed on 25 May 2021). 
25. Uppala, S.M.; Kållberg, P.W.; Simmons, A.J.; Andrae, U.; da Costa Bechtold, V.; Fiorino, M.; Gibson, J.K.; Haseler, J.; Hernandez, A.; Kelly, G.A.; et al. The ERA-40 Reanalysis. Quart. J. Roy. Meteorol. Soc. 2005, 131, 2961-3012. [CrossRef]

26. Newman, P.A.; Coy, L.; Pawson, S.; Lait, L.R. The anomalous change in the QBO in 2015-2016. Geophys. Res. Lett. 2016, 43, 8791-8797. [CrossRef]

27. Andrews, D.G.; Holton, J.R.; Leovy, C.B. Middle Atmosphere Dynamics; Academic Press: Orland, CA, USA, 1987 ; pp. 314-319.

28. Randel, W.J.; Wu, F.; Swinbank, R.; Nash, J.; O'Neill, A. Global QBO circulation derived from UKMO stratospheric analyses. J. Atmos. Sci. 1999, 56, 457-474. [CrossRef]

29. Niwano, M.; Shiotani, M. Quasi-biennial oscillation in vertical velocity inferred from trace gas data in the equatorial lower stratosphere. J. Geophys. Res. 2001, 106, 7281-7290. [CrossRef]

30. Zawodny, J.M.; McCormick, M.P. Stratospheric aerosol and gas experiment II: Measurements of the quasi-biennial oscillation in ozone and nitrogen dioxide. J. Geophys. Res. 1991, 96, 9371-9377. [CrossRef]

31. Chipperfield, M.P.; Gray, L.J.; Kinnersley, J.S.; Zawodny, J. A two-dimensional model study of the QBO signal in SAGE II NO 2 and $\mathrm{O}_{3}$. Geophys. Res. Lett. 1994, 21, 589-592. [CrossRef]

32. Hauchecorne, A.; Bertaux, J.L.; Dalaudier, F.; Keckhut, P.; Lemennais, P.; Bekki, S.; Marchand, M.; Lebrun, J.C.; Kyrölä, E.; Tamminen, J.; et al. Response of tropical stratospheric $\mathrm{O}_{3}, \mathrm{NO}_{2}$ and $\mathrm{NO}_{3}$ to the equatorial Quasi-Biennial Oscillation and to temperature as seen from GOMOS/ENVISAT. Atmos. Chem. Phys. 2010, 10, 8873-8879. [CrossRef]

33. Shibata, K.; Deushi, M. Partitioning between resolved wave forcing and unresolved gravity wave forcing to the quasi-biennial oscillation as revealed with a coupled chemistry-climate model. Geophys. Res. Lett. 2005, 32, L12820. [CrossRef]

34. Duchon, C.E. Lanczos filtering in one and two dimensions. J. Appl. Meteorol. 1979, 18, 1016-1022. [CrossRef] 